\title{
Devolution as a Means for Self-governance: Its Potential for Poverty Reduction in Kenya
}

\author{
Preston O. Chitere*, Veronica M. Ngundo \\ Department of Sociology and Social Work, University of Nairobi, Kenya \\ *Corresponding Author: pchitere@uonbi.ac.ke
}

\begin{abstract}
This study examined devolution which was introduced in Kenya at the beginning of 2013 with a view to establishing whether it was helping to reduce poverty as provided for in the Republic of Kenya Constitution (RoK, 2010). As is the case in other African countries, the majority of Kenyans are poor. We gathered data through desk reviews of relevant books, journal articles and reports and interviews with senior staff of Kakamega, Kisumu and Kajiado counties. It was evident that after abolishing Kenya's independence (1963) devolved constitution termed "Majimbo" and establishing a highly centralized governance system, Kenya implemented several deconcentration measures which included the District Focus for Rural Development, Rural Development Grants and Rural Works Program aimed at facilitating decision making and allocation and use of resources in communities. These various efforts did not lead to improvement in the country's poverty situation which stood at 56 per cent in the 1980s and 1990s. With the introduction of devolved funds such as the Constituency Development Fund (CDF) and the Local Authority Transfer Fund (LATIF) in 2003, the poverty situation had reduced gradually to 46 per cent at present. We have also shown that devolution which was introduced recently with more decision-making powers and resources had potential to ensure further reduction of poverty, especially at the county and household levels.
\end{abstract}

Keywords Devolution, Governance, Poverty, County, Resources, Constitution, Participation

\section{Background}

In March 2013, Kenya, following the national elections held in the same month, launched a devolved system of governance by adopting a new constitution. This devolved system comprises two important levels: National and County. The establishment of county governments is however complex and was being undertaken at the time of collection of data for this study.

This study examines the objectives of the devolved system, the on-going efforts at implementation of its current initial phase and its potential for reducing poverty. However, due to the system being new, this study is exploratory in nature and provides a basis for more comprehensive studies of this type in future.

Devolution is one of the components of decentralization. According to Chikulo (1999) decentralization is change in the organization of the state which involves the transfer of functions from the central to the sub-national levels or from one sub-national organization to another. Rondinelli and Nellis (1986) note that decentralization transfers or delegates legal or political authority to plan, make decisions and manage public functions from central government and its agencies to its subordinate units, semi-autonomous public corporations, area-wide or regional development authorities, local government or non governmental organizations.

Collins (1970) says that there are two main types of decentralization: Deconcentration and devolution. Deconcentration (or administrative decentralization) is the delegation of authority to the staff of a central government ministry posted outside headquarters for performance of specified functions while devolution is delegation of authority to formally constituted local government bodies for performance of specified or residual functions. Other components are discretion where an agency gives powers to an entity to perform certain functions and privatization where an agency contracts some of its functions to private service providers.

The practice of these views on decentralization and more importantly on devolution was evident at the time of independence in Kenya and especially today.

The Republic of Kenya (RoK) obtained her independence (1963) on the basis of a devolved constitution termed "majimbo" (RoK Constitution, 1963). The constitution provided for a bicameral legislature comprising an elected house of representatives and senate, the president and his deputy and the executive at regional and national levels. The constitution also provided for seven regions (Coast, North Eastern, Eastern, Nairobi, Rift Valley, Western and Nyanza) and the national and regional governments. It also provided for a public service of each region headed by a civil secretary, multi-party politics and protection of rights of minorities. 
The Constitution was amended in 1964 and 1969 thereby abolishing regional governments and multi-party politics, respectively. The 1969 amendment left the Kenya African National Union (KANU) as the only political party in the country (Muia and Chitere, 2011, 59).

This centralized system of governance was responsible for poor performance of the economy which declined from 6.6 per cent in mid-1960s to 4.1 per cent in early 1980 s, 2.5 per cent in 1990-95 and 0.2 per cent in late 1990s and associated poverty among 53 per cent of the rural and 38 per cent of the urban population with its national incidence being 52 per cent in 1997 (RoK, IPRSP, 2000, page 3). A majority of the poor households were found in districts which included those in the counties of Kakamega and Kisumu where data in this study was collected. The highest incidence of poverty (i.e., 58 per cent of the population) was found in the Arid and Semi-Arid (ASAL) districts such as Kajiado which was another site of this study.

At the time of data collection in early 2014, this high incidence of poverty had been reduced to its current level of 46 per cent owing to introduction of several devolved funds such as the Constituency Development Fund, the Local Authority Transfer Fund, the Bursary Fund, the Roads Fund and HIV and AIDS Fund.

It is our view that there is potential for further reduction of poverty following the Constitution's (RoK, 2010) devolvement of substantial funds to counties as well as an equalization fund for those that were neglected in the past.

However, since the counties are new, having been established at the beginning of 2013 , it is not possible to establish the magnitude of the effects of their efforts on poverty, but rather to isolate and pinpoint efforts being made by the counties which are likely to reduce this problem that has been persisting in Kenya.

\section{The Current Constitution: An Overview}

The amendments made to the 1963 independence constitution were repealed in 1991 and multi-partism was re-introduced. In 1997, the Inter Parties Parliamentary Group (IPPG) introduced a range of reforms aimed at ensuring fairness in the elections held later that year (Muia and Chitere, 2011). After the elections and following pressure from civil society organizations, the Kenya African Union (KANU) government initiated a review of the constitution which was not completed by the time of the next elections in 2012. The review process was continued by the new government of the National Rainbow Coalition (NARC) and prepared a fairly comprehensive constitution known as the "Bomas Constitution draft". The draft was subsequently mutilated by the then government and was not adopted (Republic of Kenya, Bomas Constitution Draft, 2004). The National Alliance of Rainbow Coalition (NARC) government which came into power in 2002 re-started the constitution making process and the document was approved by a national referendum held in 2010 and was subsequently adopted and put into practice following the national elections of December, 2012.

Prior to adoption of the Constitution (RoK Constitution, 2010), several developments helped in ensuring some empowerment of communities. One of the developments was the introduction of the District Focus for Rural Development Strategy which made districts the main units of planning and implementation of programmes (Chitere and Ireri, 2008). The other was the introduction of devolved funds: Constituency Development Fund (CDF) and Local Authority Transfer Fund (LATIF) which communities and their self-help groups accessed to improve facilities and services (Mitullah, 2011). Other funds have been centrally managed but with some elements of devolution have been the Women Enterprise Fund (WEF), the Youth Enterprise Fund (YEF), the Roads Fund and HIV and AIDs fund.

These gains in resources and decision making at the sub-national level were strengthened with the adoption of the 2010 Constitution whose objectives are to: a) Promote democratic and accountable exercise of power; b) Foster national unity by recognizing diversity; c) Give powers of self-governance to the people and enhance their participation in the exercise of the powers of the state and in making decisions affecting them; d) Recognize the rights of communities to manage their own affairs and further their development; e) Protect and promote the interests and rights of minorities and marginalized communities; f) Promote social and economic development and the provision of easily accessible services; g) Ensure equitable sharing of national and local resources; h) Facilitate decentralization of state organizations, their functions and services from the capital of the country; and i) Enhance checks and balances and the separation of powers.

The principles of the constitution are that county governments: a) Will embrace democracy entailing separation of powers; b) Have reliable sources of revenue to enable them govern and deliver services effectively; and c) Have representative bodies whose membership does not exceed two-thirds of the same gender.

These objectives and principles, emphasize self-governance and participation of members of communities in making decisions in matters affecting their lives as well as involvement of marginalized groups and communities in the governance process.

To be able to achieve these concerns of self-governance, 47 counties were created by the Constitution and they were established in March 2013. Each County has a government comprising: County assembly whose members are elected; and county executive headed by a governor and deputy governor and with appointed ministers and technical staff below them. Chapter 12 of the Constitution provides for funding of the counties and for an equalization fund for formerly neglected ones. The former local councils were dissolved and their staff and those of the national government based in the counties were to be absorbed by the county governments. 
Apart from the structural and funding aspects of the counties, the fourth schedule of the Constitution (RoK 2010) sets out responsibilities of the county governments as: Agriculture; health services; control of air and noise pollution; cultural activities; transport services; animal control and welfare; trade development and regulation; pre-primary education; natural resources, conservation and forestry; county public works and services; fire fighting and disaster management; control of drugs and pornography; and ensuring participation of communities in governance. Two key responsibilities - education (primary, secondary and tertiary) and security were not devolved to the counties. However, the lowest level of education, early childhood education (ECD) was devolved. For security, each county is required to form a community policing board headed by the governor and comprising persons concerned with security. Chapter 12 of the Constitution on finances provides for funding of the devolved units which is currently pegged at 15 per cent of total national expenditure plus a small amount as an equalization fund for needy counties.

It is clear that whereas the system of governance that has been established is not fully devolved, it provides for institutional structures, resources and decision-making with potential for increased participation of residents of counties in matters that affect their lives and ultimately their well-being.

\section{Assumption, Research Questions and Objective of the Study}

This paper is premised on the view that devolution as conceived and practiced in Kenya, Ethiopia and other countries such as Nigeria, could be a main means of poverty reduction. On the basis of this assumption, the study sought answers to a number of research questions: a) What is the development and welfare situation of the counties; b) What form does their organizational structure take? c) What is the level of their human resources? d) What is the level of their financial resources? e) Which development projects are the counties planning or implementing; and f) How far are people participating in planning and implementation of the projects? The questions in turn provided a basis for the main objective of the study which was: "To review progress made in establishment of the county governments and their potential for effective delivery of services and poverty reduction".

\section{Literature Review and Theoretical Conceptions}

Of the various forms of decentralization presented in the literature, there are the integrated administrative system, partnership, dual and the comprehensive local government system (Mutahaba, 1979). The integrated administrative system is where central government agencies administer all technical services. Whereas ultimate authority for all government functions is retained at the centre, decision making power and responsibility for implementation is delegated to field units at the local level usually headed by a prefect or coordinator assisted by committees coordinating various functions. The partnership system permits some services to be rendered directly by field units of the central government and others by local authorities while in the dual system central government ministries directly administer services while local authorities have legal authority to deliver local services. Finally, the comprehensive local government system refers to administration by local authorities of all development and welfare services.

Prior to adoption of the 2010 Constitution, the dual and to some extent partnership types of decentralization applied in planning and implementation of development and welfare services in Kenya. With the adoption of the Constitution, a lot of responsibilities have been entrusted to devolved units although a number are still administered directly by the national government implying that the system is a hybrid of the dual and comprehensive government systems.

For such a devolved governance system to operate effectively, there are a number of requirements as noted by Maddick (1963), Price (1968) and Bell (1967) including: First, there are two main levels which are national and sub-national with staff at national level making strategic while those in the field making operational decisions; secondly, staff at both levels need to be professionals - for those at the sub-national such professionalism will enable them to make decisions without frequent referrals to their superiors at the national level; thirdly, there should be conducive conditions of work that provide room for field staff to grow in service. Bell talked of high discretion units where supervisors motivate subordinates by appealing to professional and service norms and other administrative constraints; fourthly, effective coordination of field units when planning and implementing their programs; and finally, there is need for people's participation in planning and implementation of programmes achieved through cooptation and other mechanisms.

These features of deconcentrated units also apply to devolved ones such as counties in Kenya. Incidentally, from another perspective a county can be viewed as having higher and lower levels implying the need for further downward delegation of authority.

A lesson can be drawn from Ethiopia's devolution discussed by Beyene (1999) which has two main levels of federal and state which share responsibilities and revenue. There are eleven regions representing various ethnic communities. Unlike Kenya which has vast human resource capacity, Ethiopia undertook intensive training of her staff in countries such as India as well as through the Business School of the Open University in the United Kingdom and local institutions such as the Ethiopian Management Institute.

These and other structural and resource requirements if met are likely to provide an effective basis for poverty reduction. The World Bank development report (2000) 
defines poverty as the pronounced deprivation of well-being. This includes lack of income, assets, political and legal rights, basic services and sometimes discrimination. In Sub-Saharan Africa, the proportion of people living on under US\$ 1 a day was 47.4 per cent in 1990, 49.0 per cent in 1999 and was estimated to be 46.0 per cent in 2015 (World Bank Report, 2003, page 4).

Following the World Summit on Social Development in Copenhagen in 1995, the Kenya governmentprepared its National Poverty Eradication Plan (RoK, NPEP, 1999) and her Interim Poverty Reduction Strategy Paper (RoK, IPRSP) in 2000. As part of the process of preparation of the plan, surveys on poverty were carried out by the government and non-governmental organizations (NGOs) which showed the distribution and depth of poverty in the country (RoK, IPRSP, 2000). Participatory poverty assessments were also carried out in towns such as Kisumu and Mombasa which sought local people's views about poverty.The assessments measured poverty in terms of low incomes, lack of access to income-earning opportunities, lack of assets and savings, lack of access to health care and education, and poor environmental conditions. Other factors that were seen to contribute to poverty were loss of expected farm income owing, for example, to drought, seasonal variations in income, vulnerability of households to climatic changes, hazards and lack of transparency and equity in provision of basic services. The Republic of Kenya (RoK), NPEP document showed three categories of households. The 'not so poor" had regular employment or income, ate three meals a day and had children who attended school. The poor were casual workers who lacked capital to start micro-enterprises; they ate only one meal a day and had many children who did not attend school and those residing in towns were mainly tenants. The very poor relied on begging or casual work, ate only once a day and were unable to buy medicine or send their children to school.

The Republic of Kenya, Interim Poverty Reduction Strategy Paper (RoK, IPRSP, 2000) characterises the poor as landless or owning only small farm units-they lacked education, access to health care and safe drinking water, and had low-income occupations. The poor included subsistence farmers, pastoralists in Arid and Semi-Arid Lands (ASAL), agricultural and casual labourers, unskilled and semi-skilled workers, female household heads, physically handicapped, HIV/AIDS orphans and street children.

Ali (1981) had observed that a country could be transformed through substantial improvements such as reform of land tenure system that could enable its re-distribution to a large number of households or through integrated rural development programmes. Whereas we agree with these views, devolution which is currently taking root in Kenya and which transfers human and other resources as well as decision making structures and processes from the national to sub-national level is perhaps the most important means for ensuring such improvements, especially for poverty .

\section{Methods of Study}

This was an exploratory study owing to the fact that devolved governments were established in Kenya in March 2013 and had not had enough time to demonstrate their performance a year later when these data were collected and almost no studies had been carried out on them. Three counties: Kakamega, Kisumu and Kajiado were selected for this study. The reasons for our choice of Kakamega were that it was one of the most densily populated counties in Kenya and received large financial allocation from the National Treasury. Kisumu was on the other hand chosen because it had a large urban centre which bears its name and receives average allocation from the National Treasury relative to other counties while Kajiado is an arid and semi-arid area occupied largely by Masaai pastoralists and with somewhat lower allocation from the Treasury. The counties were purposively selected and were not fully representative of others and hence results of this study may not be generalizable to a large number of other counties in the country.

Senior staff of the counties were contacted and interviewed as key informants (KIs) and included: Protocal officer (KI 1) and county secretary, Kisumu (KI 2); Member of the County Executive (MCE) responsible for finances (KI 3 ) and the acting director of Physical planning, Kakamega (KI 4); and the Interim County Secretary (KI 5), County planning and development officer (KI 6) and Chief Officer, Finance, Kajiado (KI 7). The interviews were in-depth and effort was made to clarify and verify the information they provided. Secondary information was collected through desk reviews of the Constitution, report of the Task Force on Devolution, relevant Acts of Parliament, county reports and relevant journal articles and books and from the websites of the counties.

\section{Results}

\section{The socio-economic profiles of the counties}

Kakamega, Kisumu and Kajiado are among Kenya's 47 counties. Kakamega and Kisumu are smallholder areas in the western while Kajiado is pastoralist area in the southern part of the country.

Whereas Kakamega has reliable rainfall, good soils and manpower, it has a poverty rate of 53 per cent. An estimated 84 per cent of the county's population relies on agriculture for livelihood

(http://www.kakamega.go.ke/index.php/government).

A study completed by the Students from the University of Utretch (1989) on agronomic, socio-economic and development situation of several locations (currently, wards) of the county showed that whereas there were enough sources of livelihood, for example, sugarcane and dairy farming in some locations, the sources were fewer in others leading to widespread migration, especially of male 
household heads to towns and other areas in search of livelihood. Consequently 37 per cent of the households were led by women. Whereas primary and secondary schools were adequate, the teacher: pupil ratio was low. There were government and private health facilities, but they lacked better qualified staff and drugs. Housing and water supplies were poor and use of farm inputs and practices recommended by the Extension Service was low leading to food insecurity in most of the county.

Kisumu county has a shoreline on the eastern part of Lake Victoria. The county receives adequate rainfall, has favourable climate and most parts have fertile black cotton soils. (http://en.wikipedia.org/wiki/kisumu_county). Fishing is one of the main sources of livelihood although constrained through use of old technologies and the water hyacinth on the lake. Rice is grown under irrigation. Sugarcane is also widely grown and there are three factories for processing the crop. Food crops grown are maize, beans, sweet potatoes and vegetables. The capital city, Kisumu hosts several light industries in textiles, molasses, fish and agro produce processing. Cottage industries include tailoring, handcrafts and boat making

(http://en.wikipedia.org/wiki/kisumu_county). It is a major commercial centre in western Kenya and provides services such as wholesale and retail, bicycle and vehicle repairs, entertainment and IT. Several banks servicing western Kenya have regional offices in the city. A branch of the Mombasa-Uganda railway terminates at Kisumu and there is a sea transport to Mwanza, Entebbe and other important ports on Lake Victoria. The city has also an international airport which was recently improved.

Kajiado county borders the city of Nairobi and extends to Tanzania to the south. The indigenous people are the Masaai but there are a large number of people from other ethnic communities. It is a semi-arid area with annual rainfall ranging from 500 to $1,250 \mathrm{~mm}$ per annum with prolonged drought in some years. Livestock keeping is the main source of livelihood.

The socio-economic characteristics of the three counties are summarized in Table 1.

Table 1. Selected development indicators for -Kkakamega, Kisumu and Kajiado counties

\begin{tabular}{|c|c|c|c|}
\hline \multirow{2}{*}{ Characteristic } & \multicolumn{3}{|c|}{ County } \\
\hline & Kakamega & Kisumu & Kajiado \\
\hline Area in square $\mathrm{Kms}$ & 3,244 & 2,086 & 21,293 \\
\hline Population (2009 census) & $1,660,551$ & 968,879 & 687,312 \\
\hline Population density & 515 persons per square $\mathrm{km}$ & 460 persons per square $\mathrm{km}$ & 31 persons per square $\mathrm{km}$ \\
\hline Sub-counties & 12 & 7 & 5 \\
\hline Wards & 60 & 35 & 25 \\
\hline Literacy & $72.7 \%$ & $65.8 \%$ & $55.4 \%$ \\
\hline Number of public primary schools & 460 & 706 & 198 \\
\hline Primary school enrolment & 219,734 & 240,538 & 54,278 \\
\hline Ratio of primary school teachers: pupils & 1:51 public schools & $1: 51$ & Not available \\
\hline Number of public secondary schools & 145 & 173 & 42 \\
\hline $\begin{array}{l}\text { Ratio of public secondary school } \\
\text { teachers: pupils }\end{array}$ & $1: 26$ & $1: 30$ & Not available \\
\hline Universities and colleges & 1 university and several colleges & $\begin{array}{c}2 \text { universities and several } \\
\text { colleges }\end{array}$ & 1 university \\
\hline Training institutions & Several & Several polytechnics & 1 Technical training college \\
\hline Number of hospitals & 12 & 9 & 2 \\
\hline Number of dispensaries & 101 & 53 & 40 \\
\hline Infant mortality & $63.9 / 1000$ & $95 / 1000$ & $45 / 1000$ \\
\hline Under 5 mortality & $122.5 / 1000$ & $149 / 1000$ & $74 / 1000$ \\
\hline Doctor to population ratio & 1: 14,246 & Unavailable & $1: 76,000$ \\
\hline Paved roads & $4.9 \%$ & 4.9 & $5.9 \%$ \\
\hline Electricity access & $5.6 \%$ & 18.3 & $39 \%$ \\
\hline Urbanization & $15.1 \%$ & $52.4 \%$ & $41.4 \%$ \\
\hline Poverty rate & $52.1 \%$ & $45 \%$ & $40-50 \%$ \\
\hline
\end{tabular}

Source: County Internet websites 
These profiles show that the socio-economic situation varied greatly from one county to another. Kajiado with 21,393 square kms was the largest followed by Kakamega and Kisumu. However, population and its density were much higher in Kakamega and lower in the pastoral Kajiado county. There were more public primary and secondary schools and a higher school enrolment in Kisumu followed by that in Kakamega and Kajiado. There were more health facilities in Kakamega followed by Kisumu and least in Kajiado although infant and underfive child mortalities were lower in Kajiado than in the resource endowed Kakamega and Kisumu counties. Similarly, Kajiado presumably because of its proximity to the capital city of Nairobi has a slightly higher percentage of paved roads as well as access of households to electricity and urbanization. The poverty rate is, however, slightly lower in Kisumu followed by Kajiado and Kakamega counties.

Whereas this information on socio-economic profiles of the counties studied was readily gathered from the key informants and secondary sources such as strategic plans and other reports of the counties, none of the counties had carried out a detailed baseline study of its socio-economic situation and this was a major concern. Consequently some of the above socio-economic information may not have been as accurate and will require verification by subsequent studies.

\section{Organizational Structure of the Counties}

The type of devolution Kenya has adopted is not comprehensive in that of the three arms of government, only the legislature and executive have been devolved - the judiciary is still a national government function. Of the executive functions, education [(except, early childhood development (ECD)] and security (except community policing) were not devolved. The county is headed by the governor and deputy governor who are directly elected by voters of the county. There is a County Assembly comprising elected and a few nominated members (MCAs) headed by a speaker. Kakamega had 60 (48 elected and 12 nominated) members. There is also the County Executive headed by the governor and comprising Members of the County Executive (MCEs) (equivalent to Cabinet secretaries at the national level), chief officers (equivalent to principal secretaries at the national level) and directors of various ministries and departments and their staff responsible for delivery of services in the county. Within the Executive, there is the County Public Service and the County Treasury. At the lower level, there are sub-county and ward administrator positions which were in the process of being filled.

These institutions and their leaders were the key decisions making organs of the counties and consequently were responsible for their successful governance including design and implementation of various anti-poverty programmes.

In Kakamega county, 8 sectors had been identified and their MCEs had been appointed: Agriculture and rural development; health services; education, science and technology; transport, infrastructure and public works; lands, physical planning and urban development; labour, social services, culture, youth and sports; trade, tourism and industrialization; and environment, water, energy and natural resources.

In Kajiado, it was noted: "Like other counties, we are in the process of forming structure. Now we have ministries which have been devolved according to the constitution and MCEs who have been recruited... Under them are chief officers who are in process of being recruited... Further, below are directors of various departments who are responsible for functions inherited from the central government. Sub-county and ward administrators were yet to come on board" (KI 6).

It is conclusive that county institutions are still in formative stage and have potential of being closer to people and more responsive to communities when fully established and operational.

\section{Human Resources}

The Constitution (Republic of Kenya Constitution, 2010), the Republic of Kenya Report of the Task Force on Devolution (2010) and the National Transition Authority (http://wwwtransitionauthority.go.ke/index.php) have guided recruitment and deployment of manpower by the counties.

Counties are headed by elected governors assisted by deputy governors who are also elected. There is a County Assembly headed by a Speaker and a County Executive headed by the Governor and Deputy Governor. In all the counties, the county executive which was in formative stage had three types of staff: New staff that were being recruited by the county; former central government staff; and former local authority staff.

Each had established the County Public Service responsible for recruitment of staff-senior ones had to be vetted by the County Assembly.

At the time of study, the governor of Kakamega held a master degree in accounting and had been a former national Minister of Finance and Planning, the governor for Kisumu also held a master degree with vast experience from the corporate world while the one for Kajiado held a master and Ph.D. degrees in community development and rural livelihoods with considerable experience working among pastoralist communities. Their deputies were equally high caliber persons.

The new staff that were being recruited in the study counties included county secretaries, protocol officers, Members of the County Executive (MCEs)(who are the equivalents of cabinet secretaries at the national level and in charge of various sectors), chief officers (equivalent to principal secretaries at national level) and Directors of various departments. For example Kakamega had recruited Members of County Executive (MCE) for its eight sectors. One of the MCEs responsible for finance whom we interviewed held a master degree in business administration 
and finance with substantial associated experience. The Kisumu County Secretary held a master degree in public policy with associated experience from corporates. The county was planning to recruit ten chief officers with equally high qualifications and experiences (KI 2).

The county secretaries, chief officers and directors were being appointed through a competitive process by the County Public Service and vetted by the Assembly. However, one of the Key Informants (KI 1) did not have similar high level qualifications and said that he had been a strong supporter of the governor implying that some of the appointments might be political and not based on professional qualifications.

In Kajiado county, the following progress had been made in regard to various key appointments (KI 7):

a. Positions of ten chief officers were advertised, interviews were held and vetting done by the County Assembly and half had taken up the appointments at the time of study;

b. An interim County Secretary responsible for arranging cabinet meetings and conveying its decisions to the MCEs and chief officers for implementation had been appointed;

c. Positions of sub-county administrators had been advertised, interviews done and the recruited persons were expected to report; and

d. Positions of directors who are technical staff in charge of departments were advertised and interviews had been held and they were about to report.

Key informants from both Kakamega (KI 3) and Kisumu (KI 2) noted that the counties were planning to recruit directors of various services. Kakamega had already identified acting directors who were heads of various technical ministries and departments.

At sub-county and ward levels, both Kakamega and Kisumu were in the process of recruiting administrators (KI 3).

The national government staff who number up to 1000 or more in any one of these counties and who are in charge of work of their sectors such as agriculture and health have been brought under the MCEs and chief officers. In Kajiado it was noted that the staff were already being paid by the county (KI 7).

A major problem that was facing the counties was that of harmonizing the staff that they were recruiting with the large number of national government staff who continued to be located and serve in the counties. Some of the staff, e.g., health had been unwilling to serve under counties but had been prevailed upon by the national government to do so (KI 7). Similarly while the former local authorities were dissolved and their staff automatically re-located to the counties, formation of structure such as boards responsible for towns and municipalities was yet to be done in counties such as Kakamega and Kisumu (KI 3). Their staff are to be vetted by the County Public Service Boards before being confirmed - this was yet to be done in the counties studied.
The governor, Kakamega is quoted as saying... "The main challenge facing the county government is developing a human resource composed of staff who are willing to work hard to deliver services to people of the county. The culture of former municipal council workers has been very different. Weak financial controls... and untrained employees... is something we must tackle"

(http://www.kakamega.go.ke/index.php).

Another challenge was that of the former provincial administration whose staff had been re-designated as regional and county commissioners answerable to the national government. The constitution says that:

"Within five years of the effective date, the national government shall restructure the system of administration currently known as the provincial administration to accord with and respect the system of devolved government established under this constitution"(RoK Constitution, 2010 Schedule six, Article 17, page 199).

The governor of Kakamega said:

"officers of the defunct provincial administration have not yet... (appreciated)... the idea of county governments well and there exists a strained relationship with the county governments. Communication has been very poor and knowing what is happening from the national government has been impossible"

(http://www.kakamega.go.ke/index.php).

The National Transition Authority was to ensure harmonization of staff but had not done so and the recommendations of the Task Force on Devolution were also not enforced.One KeyInformant commented:

"We are in the process of harmonizing staff. County Public Service Board has been formed...It is responsible for recruitment and human resource issues including development policy" (KI 5).

The Provincial Administration which is quoted here has been a major arm of the former national government. It was and continues to be located in the office of the President of the country. The administration hierarchy was made up of the Head of the civil service (Chief Secretary), Provincial Commissioners, District Commissioners, District Officers, Chiefs and assistant chiefs at the lowest level. The staff were the Chief Executive officers (CEOs) of their areas and oversaw all government staff and operations, but more importantly were responsible for ensuring law and order. In 2005, the Provincial Administration had nearly 2,600 high calibre staff holding bachelor, master and in a few cases Ph.D degrees and some had considerable work experience (Chitere, 2005).

The Republic of Kenya, Bomas draft Constitution (2004) had recommended abolition of the administration and re-deployment of its staff once the Constitution had been adopted but this did not happen. The 2010 Constitution provides for phasing out of the administration five years from the date it came into effect. So far, owing largely to 
political reasons, no efforts have been made to phase out the administration. This has in effect meant that, contrary to the Constitution, the provincial administration continues to operate parallel to the counties which is what the Governor's above quote implies.

Harmonization which is alluded to by the other Key Informant is critical owing to the fact that staff of the former central government and local authorities continue to be located in the counties which have also been recruiting their own new staff. This has not only led to a high wage bill but in some instances to tensions between the staff and the new county governments.

\section{Financial Resources}

Chapter 12 of the Constitution [Republic of Kenya Constitution, 2010 (Articles 201 (1) and 203 (2)] on public finance provides that revenue raised nationally shall be shared equitably among the national and county governments and that for every financial year the revenue allocated to county governments shall not be less that 15 per cent of all revenue collected by the national government. In addition, there will be an equalization fund of 0.5 per cent of the revenue collected by the national government each year [(Article 204 (1)].

The constitution also provided for establishment of the Commission on Revenue Allocation which is responsible for making recommendations about the basis for equitable sharing of revenue raised by the national government [(Article 216 (1)].

The Republic of Kenya Public Finance Management Act (2012) which operationalized the above chapter of the constitution, provides for establishment of: The County Treasury to manage its finances, the MCE member for finance as head of the treasury and its chief officer. The Act provides further that in the medium term 30 per cent of the county budget shall be allocated to development expenditure.

Following completion of the elections in March, $2013 \mathrm{Ksh}$ 190 billion (currently Ksh.92 = US \$ 1) was set aside for disbursement to the counties. Kakamega, Kisumu and Kajiado counties were allocated Ksh 6.52, 4.16 and 3.23 billion, respectively. However, the disbursements are done quarterly and for the July-October, 2013 period, 27 billion was disbursed but only 25 per cent was spent by the counties (Daily Nation, $9^{\text {th }}$ January , 2014, page 5). The low level of expenditure was owing to failure of most counties to meet the conditions for release of funds as specified in the Public Financial Management Act (2012). Most counties had not prepared their procurement plans to ensure utilization of funds as soon as they were disbursed, or had not prepared balanced budgets, or had unrealistic estimates (Daily Nation, $9^{\text {th }}$ January , 2014, page 5).

More of the money was spent on personal emoluments followed by operations and maintenance, development and servicing debts and pending bills.

For the fiscal year 2014/15, Ksh 242 billion was disbursed to counties (Daily Nation, March $2^{\text {nd }}, 2014$, pages 15-16). The largest amount of Ksh 13.04 billion went to Nairobi while the lowest Ksh 2.4 billion went to Tharaka Nithi county. Kakamega, because of its large population, was the third in the allocations with Ksh 8.8 billion while Kisumu and Kajiado received Ksh 4.86 and Ksh 3.76, respectively.

The allocations are made on the basis of three criteria: population; land area and poverty levels as noted by the Cabinet secretary for Treasury:

"The parameters used to measure the expenditure needs of counties were population accounting for 45 per cent of the allocation...land area for 8 per cent and poverty levels for 20 per cent... It can be argued ...that when county governments are allocated resources on the basis of this formula, their developmental needs... are adequately taken care of..." (Daily Nation, March $2^{\text {nd }}, 2014$, page 16).

The funds are spent on the basis of a budget prepared participatorily by various stakeholders. In Kajiado, the Interim county secretary noted:

"The budgeting process is done at a certain time and people participate through forums from ward level upwards. Last week we had a forum at which we presented the County Fiscal Strategy Paper to the public... Finance bill is passed by the County Assembly and presented to the public for suggestions and recommendations" (KI 5).

It is worth clarifying that whereas the counties studied were making efforts to involve stakeholders in their budgeting process as provided for by the Constitution and the Finance Act of 2012, the capacity of the forums, especially those in Kakamega which we observed was somewhat low. For example, while the forums came up with long lists of projects for funding, which would, if implemented, go along way to reduce poverty, they appeared not to be conversant with the need for prioritization of the projects.

In Kakamega, the MCE for finance (KI 3) noted that apart from the allocations by the Treasury, the county expected to raise an additional Ksh. 2 billion while one Key Informant in Kajiado (KI 7) noted that the county expected to raise Ksh 1 billion. In the latter county the amount was to be raised through cess, rates, licenses, entertainment, taxes, market fees, advertisements and other levies (KI 7). These sources of revenue are specified in Chapter 12 of the Constitution and include borrowing from international sources with approval from the National government.

Whereas these revenue collections will supplement the allocation by the National Treasury and increase resources available to counties for their operations, they need to be done carefully so as not to overburden their residents who are already paying large amounts of tax to the national government. 


\section{Development and Welfare Projects}

The counties had prepared Integrated County Plans on the basis of guidelines provided by the Ministry of Devolution and Planning but were not finalized in the three study counties. The plans were prepared between July and October, 2013 and provided a basis for the county budgets which reflected unique circumstances of each. Tendering process also took time. Consequently, involvement of counties in development work as envisaged by the Constitution was yet to start. However, a few projects had been conceived or launched (Table 2).

For Kakamega, its development priorities were listed as agriculture - ten per cent of the budget was to be invested into it and thereby build a base for agro-industry (http://www.kakamega.go.ke/index.php/government).

Whereas sugarcane farming was to be strengthened, emphasis was on diversification of agriculture - that is, apart from sugarcane farming, dairying, horticulture, fish farming, coffee and tea were to be encouraged aimed at creating employment and reducing poverty. Polytechnics were to be equipped and strengthened so as to provide youth with skills for employment. Through the use of soft loans, the county was to support local commerce by establishing modern markets as well as support of informal and formal businesses including cottage industries. Sub-county hospitals were to be equipped and the referral hospital refurbished and equipped including employment of more nurses and clinical officers.

Other plans included, improvement of road networks and clean-up and beautification of towns. The governor was quoted as saying... "I am confident that (within the next five years) all the MDGs will have been realized".

Majority of Kisumu's residents were of the Luo ethnic community but there were also a few Luhyas, Indians and members of other communities.

The county, among other things planned to eradicate the hyacinth on the lake, improve fishing technology and develop Kisumu port and make it a regional centre of water transport and Kenya's gateway into the rest of the African Great Lakes Region

(http://en.wikipedia.org/wiki/kisumu_county).

Table 2. Development Projects at Conceptual of initial implementation stage in Kakamega, Kisumu and Kajiado.

\begin{tabular}{|c|c|c|c|}
\hline \multirow{2}{*}{ Type of Project } & \multicolumn{3}{|c|}{ County } \\
\hline & Kisumu & Kakamega & Kajiado \\
\hline ECD Teachers & 700 posts advertised & & \\
\hline Transport & $\begin{array}{l}\text { Sea transport - county signed agreement with a } \\
\text { Canadian firm to strengthen navigation in Lake } \\
\text { Victoria. The county also signed an MoU with } \\
\text { Kenya Maritime Authority and the Kenya } \\
\text { Docks Authority for development of beaches } \\
\text { where ships will be docking }\end{array}$ & & $\begin{array}{l}\text { Improvement of bus parks has } \\
\text { started } \\
\text { Ksh } 250 \text { million was allocated } \\
\text { for improvement of roads } \\
\text { networks }\end{array}$ \\
\hline Tractor services & $\begin{array}{l}19 \text { tractors are acquired and are to be given to } \\
\text { farmers }\end{array}$ & & \\
\hline Health services & & $\begin{array}{l}\text { Improvement of health ser vises has } \\
\text { been started }\end{array}$ & Ksh 200 million \\
\hline Tourism & Western Kenya circuit is to be developed & & Ksh 250 million \\
\hline Stadium & Kisumu stadium is being improved & & \\
\hline New estates & Private developers are being facilitated & & \\
\hline Education & $\begin{array}{l}\text { Ksh. } 35 \text { million was disbursed as bursaries to } \\
\text { needy children while the governor sponsored an } \\
\text { additional } 6 \text { pupils }\end{array}$ & & $\begin{array}{l}\text { Ksh } 150 \text { million allocated for } \\
\text { schools and polytechnics }\end{array}$ \\
\hline Agriculture & $\begin{array}{l}\text { Food security: Farmers to be given millet seed } \\
\text { for planting } \\
\text { Cash crops: Cotton industry is to be } \\
\text { revived-Governor visited Bukina Faso where } \\
\text { cotton is the main cash crop }\end{array}$ & $\begin{array}{l}\text { Horticulture, dairying, vegetables, } \\
\text { sugarcane and cooperatives: These } \\
\text { are to be improved and sugar } \\
\text { companies are to be encouraged to } \\
\text { permit farmers to grow the crop and } \\
\text { deliver to factories }\end{array}$ & Ksh 180 million \\
\hline Fishing & $\begin{array}{c}\text { Fishing nets factory which has been based at } \\
\text { Thika is to be established at Kisumu }\end{array}$ & & \\
\hline Water & & & Ksh 120 million \\
\hline Financial support & $\begin{array}{l}\text { Women groups and youth groups are to be } \\
\text { given support beyond the national Uwezo and } \\
\text { WEF support }\end{array}$ & & \\
\hline $\begin{array}{l}\text { School buildings } \\
\text { and water dam }\end{array}$ & & & $\begin{array}{l}\text { Ksh } 300 \text { mi allocated to new } \\
\text { schools as well as separating } \\
\text { girls from boys. }\end{array}$ \\
\hline Infrastructure & & & Ksh 200 million \\
\hline ICT & & & Ksh 30 million \\
\hline
\end{tabular}


Kajiado's plans included: Improving horticultural farming to meet needs of local residents and export markets; supporting industrial development - processing of milk and meat and real estate development in metropolitan areas bordering the city of Nairobi as well as the proposed Konza city at the boundary of this county and its neighbor, Machakos. The county was also to explore possibilities for mining of limestone in Loitoktok and Bissil areas and soda ash at Magadi. It was also to promote tourism in Amboseli National Park.

Other planned projects or those that were being implemented are presented in Table 2.

\section{People's Participation}

This is provided for either directly or indirectly by the constitution and associated Acts of the National Assembly.

Article 117 (1) of the Republic of Kenya Public Finance Act (2012) which operationalized Chapter 12 of the Constitution provides that... "the county Treasury shall prepare and submit the County Fiscal Strategy paper for approval by the County Assembly by $28^{\text {th }}$ February of each year. In preparing the paper, the treasury shall take into account the views of the public, any interested persons or groups and any other forum that is established by legislation".

In preparation of the county budget, Article 125 (1) of the Act requires the MCE for Finance to ensure public participation in the budget process.

In Kakamega, a Budget and Economics Forum of 12 members was formed (KI 3). The forum was chaired by the governor and its members were professionals and representatives of special interest groups such as women, elderly, youth, disabled and faith based organizations. The sub-county forums sent representatives to the county one.

At the meeting of the budget forum for Kakamega central sub-county at Kakamega social hall on $20^{\text {th }}$ February, 2014 which the first author of this article attended, participants who numbered about 50 were briefed by the MCE, Finance of the process and importance of their views.

When opening the stakeholders' meeting on preparation of the county's budget, the MCE for Finance, among other things, said:

"...Constituion of Kenya 2010 says that people have to be involved in making decisions...(It) requires us to be here for this exercise... (I) call on you to give your views for various sectors...in the past development was done without consultations...Finance Chapter 12 of the Constitution (2010) calls for finance and budget forums representing various groups to participate. The purpose of this meeting is to give your views on the budget (KI 3 ).

One stakeholder group had prepared a written memorandum for presentation at the meeting but was advised to submit it to the MCE for Finance.
The participants were then divided into small groups each handling concerns of a sector. The group concerned with labour, social services, youth and sports sector proposed a large number of projects for the 2014/15 financial year budget including:

- Need for holding of tournaments at local level;

- Athletics should be held in the county to cater for many youths who were talented and attract outsiders;

- Youth centres existing in some constituencies should be equipped and new ones established where they do not exist;

- Need for establishment of youth and women advisory boards to oversee implementation of the one-third gender rule in elective and appointive positions

- Need for employment of a specialist for talent identification at all levels;

- Need for the main county stadium, Bukhungu to be up-graded to national standard with facilities and equipment;

- Need for Emalinya sports ground to be up-graded;

- Purchase land and establish sports grounds in every sub-county;

- Start a county cultural day;

- Finance improvement and preservation of the site for the "crying stone"

- Establish Arts gallery;

- Improve libraries in all schools; and

- Establish a rescue centre for needy children.

This long list approximates what Chambers (1974) termed a shopping list of projects. Similar lists were prepared by other groups within the same meeting as well as by other forums in other wards. While some of the proposed projects were short- term, others were medium and still others were long-term. This implied that the county forum must have had a difficult time prioritizing and selecting those to be funded.

In Kajiado, the Budget and Economic Forum had been established as per the Finance Act (KI 7). Experts from various sectors were to discuss the budget and make their recommendations. The Chief Officer, Finance commented:

"... As soon as the draft will be ready, citizens will be engaged at ward level through barazas - we get suggestions and we also give them our recommendations and seek their prioritization. We ensure it is inclusive-women, disabled, youth... we give community chance to prioritize what it wants. Each ward picks two projects...we cost the projects...People are able to make decision... . we are able to interact with them...they decide what they want...there is ownership" (KI 7).

Unlike Kakamega where the stakeholder forums were formed at ward levels and there was potential for their capacities to be enhanced for effective participation in budget preparatin, in Kajiado, the use of barazas which are public meetings did not have equal potential of ensuring effective participation and feedback from members of the communities. 


\section{Conclusions and Recommendations}

The socio-economic profiles of the counties show them to be characterized by poverty as evident in their overall poverty rate and related indicators such as high population densities, especially for Kakamega and Kisumu, low literacy level, especially for Kajiado, high teacher:pupil ratio, lack of enough training facilities, high infant and child mortality, high doctor-patient ratio, few $\mathrm{kms}$ of paved roads, low electricity consumption and low rate of urbanization, especially of Kakamega.

The organization structure of the counties show that they have established institutional frameworks of assemblies and executives as well as sub-county and ward level offices which are key in decision making relating to mobilization and effective use of resources for poverty reduction.

Human resources were fairly abundant in the counties in the form of national and the former local authority staff as well as the new staff that the counties were recruiting. A main challenge was harmonization of the staff which was being undertaken and which, if well done, would provide the human capacity needed for planning and implementing of poverty reduction programmes.

Unlike in the past when the national government was responsible for allocation and control of resources through its ministries, this time round the national Treasury was allocating resources to counties which were in a much better position to plan and use them in beneficial ways. The few projects cited show potential for more similar ones being undertaken in future with further potential for faster reduction of poverty.

Whereas members of communities were not sampled and interviewed in this study, the authors who are also residents of these counties have observed a lot of economic activities including selling of building materials such as stones, sand, bricks, poles and timber by households. Local groceries, hotels and other small businesses are beginning to thrive. Local contractors are engaged in construction of schools, health facilities, access roads and other infrastructural facilities funded by the counties. Food items such as vegetables are also finding a ready market. These and other livelihood sources will be confirmed by future studies.

Perhaps a major observation of this study which, we did not anticipate is that major transformations can come through a decisive macro level change, such as the new Constitution which has brought far reaching structural and operational changes in Kenya's governance with considerable potential for poverty reduction.

From the above results, the recommendations are evident: Human resources: There is a growing human resource capacity which, if strengthened through appropriate training and relevant exposures, could facilitate development of the counties and reduce their poverty. There is need, however, for re-orientation of a large number of the staff for service in the counties through appropriate training programmes mounted by universities and other educational institutions as well as through relevant exposures. For example, the staff could be trained in participatory approaches and techniques including situation analysis, identification and prioritization of problems, design and implementation of projects and monitoring and evaluation;

Supplementing of revenues allocated by National Treasury: The commitment by all counties studied to supplement funds allocated to them was positive and should be encouraged by he Treasury but guided so as not to lead to over taxation; People's participation: (2010) There is need for creation of more awareness among residents of the counties about what county governments are as well as building of their capacity that can enable their effective participation in decision making in the affairs of the governments;

Profiles of the counties: These show that each has unique potential for large, medium and small scale projects which, if effectively identified, planned and implemented, could increase employment and in consequence reduce poverty. There is, however, need for each county to carry out baseline study of its situation and to continually up-date the data and even establish a data bank of itself. None of the counties studied had started with gathering baseline information about its current state of development and welfare. Whereas a lot of information exists on each of the counties, it needs to be assembled to show the current state and be continuously up-dated.

\section{REFERENCES}

Ali, A.A.G. 1981 The effects of rural transformation. In: Okoth-Ogendo, H.W.O., editor, Approaches to rural transformation in Eastern Africa. NAIROBI: Bookwise Ltd

Bell, G.D., 1967 Formality versus flexibility in complex organizations. In: Bell, G.D., ed., Organization of human behavior, New Jersey: Prentice-Hall, Inc.

Beyene, A. 1999 Decentralization as a tool for resolving the national problem: The Ethiopian Experiment. Paper presented at the Inter-regional Workshop on Decentralization for Good Governance and Development, Boulevard Hotel, Nairobi, 26-27th August.

Chambers, R.1974 Managing Rural Development: Ideas and Experience from East Africa.Upsalla: Scandinavian Institute of African Studies

Rondinelli, D.A. and Nellis, 1986 Decentralization and development: Policy implementation in developing countries. Beverly Hill: Sage Publishers

Chikulo, B.C. 1999 Decentralization for good governance and development: the Zambian experience. Paper presented at the Regional Workshop for Good Governance and Development, 28-30 July, Nairobi.

Chitere, P.O. and Ireri, O. 2008 District Focus for Rural Development as a Decentralized Planning Strategy. In: Kibua, T.N. and Mwabu, G., eds, Decentralization and Devolution in Kenya. Nairobi: University of Nairobi Press

Chitere, P.O. 2005 The Provincial Administration in Kenya: Its characteristics and options for the future, Institute of Policy 
Analysis and Research, Discussion Paper No.074, Nairobi.

Collins, P. 1970 The working of the Regional Development Fund: A problem in decentralization in rural Tanzania. In: Proceedings of Provisional Council for Social Sciences in East Africa, Dar es salaam, Vol V

Daily Nation Newspaper 2014 Issues of 9th January, page 5 and 2nd March, page 16

Maddick, H. 1963 Democracy, decentralization and development, London: Asia Publishing House

Mitullah, W.V.2011 Constituency Development Fund: Issues and Challenges of Management. In: Chitere, P.O. and Mutiso, R., eds, Working with rural communities, Nairobi: University of Nairobi Press.

Mutahaba, , G. 1979 Decentralization as an aid to development. Paper presented to the workshop on alternative patterns on development and lifestyles in Eastern Africa, Nairobi.

Muia, D. and Chitere, P. 2011 Devolution of functions and authority to sub-national government in Kenya: Reflections on capacities of villages, locations and districts for self-governance. In: Chitere, P.O. and Mutiso, R., eds, Working with rural communities, Nairobi: University of Nairobi Press.

Price, J. L. 1968 Organizational effectiveness. Illinois: Richard Irwin, Inc.
Republic of Kenya 2012 Public Finance Management Act. Nairobi: Government Printer

Republic of Kenya 2010 The Constitution of Kenya. Nairobi: Government Printer.

Republic of Kenya 2010 Final Report of the Task Force on Devolved Government, Vol. 1, Office of the Deputy Prime Minister and Minister for Local Government, Nairobi

Republic of Kenya, 2004 The Bomas Draft Constitution, Nairobi: Government Printer.

Republic of Kenya, 2000 Interim Poverty Reduction Strategy report, Nairobi: Government Printer.

Republic of Kenya, 1999 The National Poverty Eradication Plan. Nairobi: Government Printer.

Republic of Kenya 1963 The Constitution of Kenya. Nairobi: Government Printer

University of Utrecht Students 1989 Kakamega District Focus Project: Location development profiles, District Development Officer's office, Kakamega

World Bank

2003http://www.worldbank.org/data/wdi2003/worldview.htm. 